\title{
In Pursuit of the American DREAM, or Mirage? Undocumented Youth in YA Fiction
}

\begin{abstract}
The problems of undocumented youth in contemporary American immigrant fiction have been given a major focus, as political shifts and competing agendas fuel an ongoing national debate. Especially for young people who are on the brink of adulthood, their status as documented or undocumented results in inclusion in or exclusion from social, economic and political spheres, which affect their daily experiences and influence their plans for the future. This paper will explore the ways in which illegal status informs, impacts, and shapes the protagonists' identity. The concept of undocumented status is used in my paper as an analytical lens through which the novels are read. My choice of the comingof-age genre reflects the importance of adolescence as a crucial period in the formation of a person's identity. I argue that young adult fiction with undocumented protagonists on the one hand gives voice to those who are silenced and forced to live on the margins of American society, and on the other hand familiarizes native-born Americans with the social struggles that might be distant from their own experiences but offer alternative ways of looking at the world. The narratives about "Dreamers" are part of a broader political discourse on the U.S. immigration. By exploring the relationship between fiction and the dominant legal system, they signal current social issues and offer a critique of exclusionary practices of American law and society.
\end{abstract}

Key words: YA fiction, undocumented, immigrants

The problems of undocumented youth ${ }^{1}$ in contemporary young adult (YA) literature have been given a major focus, as political shifts and competing agendas fuel an ongoing national debate. President Barack Obama's immigration policy (2008-2016),

1 The Development, Relief and Education for Alien Minors (DREAM) Act (2001) is a way to provide residency to undocumented young people who arrived in the USA as minors, and who attend college or serve in the military for at least two years. Deferred Action for Childhood Arrivals (DACA) (2012) refers to undocumented children brought to the U.S. before 
and later President Donald Trump's presidential campaign (2016) addressed the problem, albeit from two different ends of the political spectrum. The political shift to the more radical approach of the newly elected President, which stripped protection from the Dreamers, launched a national debate which continues to divide American society. Especially for young people on the brink of adulthood, described by Rumbaut as the 1.5 generation (Generation 1.5), their status as documented or undocumented results in inclusion in or exclusion from social, economic and political spheres, which affect their daily experiences and influence plans for the future. This paper aims to show the ways in which illegal status informs, impacts, and shapes the protagonists' identity. I focus on juvenile fiction with undocumented protagonists who share a stigmatized collective identity, and who are brought to America at an early age: Maria E. Andreu's Secret Side of Empty (2014), Melissa de la Cruz's Something in Between (2016), and Sara Saedi's Americanized: Rebel Without a Green Card (2018). The selected novels have been published within the last five years, and hence offer up-to-date commentary on the situation of undocumented youth in American society. They have been penned by female authors and portray female protagonists, a consistency which, I believe, helps to build an accurate literary representation, but also shows a variety of experiences within. Even though undocumented youth of both sexes face the same structural limitations, the social position of women propels them to experience and negotiate their illegality differently from men. Hence, the focus of my study are female YA protagonists, who navigate their gendered expectations towards the experience of immigration and struggle to make their undocumented status relevant.

The concept of an undocumented status is used in my study as an analytical lens through which the novels are read. My choice of the coming-of-age genre reflects the importance of adolescence as a crucial period in the formation of the person's identity. Since its inception in Germany in the $18^{\text {th }}$ century, coming-of-age has been a well-established genre in American literature, represented by such masterpieces as The Adventures of Huckleberry Finn by Mark Twain (1884), Catcher in the Rye by Jerome D. Salinger (1951), and To Kill a Mockingbird by Harper Lee (1960). Immigration to America and assimilative struggles of the protagonists constitute an important part of this fiction, from Mary Antin's The Promised Land (1912) and Betty Smith's A Tree Grows in Brooklyn (1943), to Sandra Cisnero's The House on Mango Street (1984), Marina Budhos' Ask Me No Questions (2006), Juno Diaz's The Brief and Wondrous Life of Oscar Wao (2007), Jean Kwok's Girl in Translation (2010), and Thanhha Lai's Inside Out and Back Again (2011). Apart from moral growth, which accompanies the formation of the self, the confrontation with the adult world with its pressures and expectations induces the protagonist's awareness of the self. I argue that YA fiction with undocumented protagonists on the one hand gives the voice to those who are forced to live on the margins of American society, and on the other hand familiarizes native-born Americans with social struggles that might be distant from their own experiences but offer alternative ways of looking at the world. Reading texts

the age of 16, who are temporarily authorized to live and work in the U.S. without fear or threat of deportation for a two-year, renewable period. President Trump ended DACA on September 5, 2017 putting an expiration date on the legal protections granted to roughly 800,000 people known as "DREAMers," who entered the country illegally as children. 
that are meaningful to their own lives provides other immigrants with an opportunity to sympathize with the shared experience, finding in it a collective strength. Conversely, it also helps to shape how young Americans perceive such concepts as immigration and citizenship, which are key to the making of their society. To expose immigrant and native-born readers alike to such fiction may act as a springboard to a richer understanding of their own lives and the world around them. Finally, narratives about Dreamers are part of a broader political discourse on the U.S. immigration. By exploring a relationship between fiction and the dominant legal system, they signal current social issues and offer a critique of exclusionary practices of American law and society.

Reflecting the multicultural texture of American society and its immigrant segment, the protagonists come from different ethnic and religious backgrounds: Andreau's Monserrat Thalia (aka MT) is Argentinian, Cruz's Jasmine is Filipino, and Saedi's Sara is Iranian. MT is a baby when they come to America, Jasmine is nine, and Sara is two, so their recollections of the native country are at best blurry. All three novels are set in California and the choice of place is not accidental, as Jasmine's parents explain: "We came here because it's easier on immigrants generally. Schools can't report undocumented students, and they don't do a lot of workplace raids" (Cruz 40-41). In fact, California is a sanctuary state, which limits how much local law enforcement can cooperate with federal authorities to enforce immigration law. ${ }^{2}$

The reasons why they come to America reiterate the familiar American Dream discourse of financial opportunities and tolerance, even though their individual motives for coming are different. Seeking economic advancement and better prospects for their children, both MT's and Jasmine's parents decide to emigrate from Argentina and Philippines, respectively. However, MT's father "wanted to save up money and go back home to start a little business" (Andreu 30) in Argentina, so the U.S. was to be only a temporary stop that would enable the family a better start back home. Jasmine's parents, on the contrary, decide to move to the U.S. permanently, hoping that America will bring more opportunities and a better life than what they had in the Philippines. Sara's parents, in turn, are an example of forced emigration, as they flee Iran under the Ayatollah's regime, looking for freedom and tolerance in America. In all three cases they are admitted on temporary visas; once they expire they become liable for deportation.

In Cruz's and Saedi's novels, the crucial moment when the protagonists learn the truth about their undocumented status comes at the beginning of the story, becoming an overarching thread of the narratives. When Jasmine wins a National Scholarship Award and hopes for a brilliant academic career, her parents inform her that there will be neither scholarship nor college since their working visas had long expired. The juxtaposition of an outstanding academic achievement with the harshness of life shatters her entire world and undermines her efforts: "It feels like there's no ground beneath me, like everything I've ever done has been a lie breaking apart, shattering. Who am I? Where do I belong?" (Cruz 42). Sara learns about her legal

2 The California Values Act (Senate Bill No. 54, de Leon) from October 5, 2017 curtails the use of state and local resources from engaging in deportations and creates safe spaces (schools, court houses, health facilities) for undocumented persons. 
situation in a more lighthearted way, hearing her older sister complain that without a Social Security number she would never find a job. At the age of thirteen, Sara had no idea that such numbers even existed, as her parents did not involve her in important family issues. Enjoying her carefree childhood, she was oblivious of her family's problematic status until that moment, and its realization turns her entire world upside down. In the case of Andreu's novel, MT had already known the whole truth a few years earlier, having overheard her parents quarrel about her going to school: her father wanted her to stay at home for fear of being discovered and the whole family deported. So, it is not a traumatic revelation but a casual afternoon with her friends, during which she meets her love interest, that begins the narrative. However, the seemingly carefree depiction of a teenage life with chats about boyfriends, clothes, and parties is haunted by her secret.

A central feature of adolescent life is the desire to fit in, and this is also what immigrants at times strive for and at times are forced to do, although the realization of their disadvantaged legal status and a constant fear of being discovered makes this endeavor even more traumatic for the protagonists. At first, they are terrified about how their friends will react to the news, as they dread being rejected and ostracized: Sara is "too afraid of how girls who'd been born in America would judge [her]" (Saedi 21), adding: "[ $\mathrm{t}]$ hey'd probably want nothing to do with me once they learned I technically wasn't allowed to be living in the country. If this got out, I could lose everything" (Saedi 9). MT also worries about her friendship with American-born Chelsea: "I can't get over the thought that she would pull back in disgust that she's been having a sneaky little illegal in her life all this time. That somehow I've infiltrated her pure, perfect, charmed life and made it dirty" (A 55). Sara sees herself as a criminal, MT as "[t]he dirty, ugly outcast" (Andreu 139), and Jasmine as "nobody" (Cruz 42), adding: "how frustrating it is that a law can somehow define who you are or how you see yourself. It's like I'm somehow less of a person because I'm not in America legally" (Cruz 182). They all feel ashamed of themselves and lonely.

That is why they keep it secret, finding no words good enough to talk about their predicament to their peers: "How would I explain anything that's going on in my life to them? It would sound so ridiculous, so impossible next to the lives they're living" (Andreau 13). So they keep avoiding the truth: "if I don't tell anyone, maybe it won't be true." (Cruz 43). The mental burden, however, puts a strain on their relationships with other kids: "You're always so sad or mad, like you're unhappy with me and you won't tell me why. I just feel so guilty around you all the time" (Andreu 142), observes MT's friend Nate. Their inability to find a solution makes them feel trapped: "I can't think of a way out, even though I think and think about it all day. And I am too disgusted and ashamed to ask anyone what to do (Andreu 152 italics in original), while their lives are in limbo: "Who am I? Where do I belong? I'm not American. I'm not a legal resident. I don't even have a green card. I'm nothing. Nobody. Illegal" (Cruz 42). At times, the pressure gets too high, and they desire to divulge the secret: "I need to let people know what's eating at me, what's happening to my family" (Cruz 185); however, such efforts are soon thwarted by their parents, who warn them of the consequences: "You better watch your step. Keep your mouth shut. These people in this country are not your friends" (Andreu 164). When the moment of truth comes at the end of the stories, it has a cathartic value: "I put my face in my hands and the sobs come hard. Sudden. I feel the fear washing out of me, leaving me 
more tired than I've felt in a long time, but a little exhilarated, too" (Andreu 162). It is not only letting friends know that they are undocumented, but the greatest fear is to face the fact that this is who one is at the moment. Coming out to oneself is the greatest challenge, but also the biggest reward. This act of empowerment allows them to exercise a little bit of control over their lives and restores a sense of dignity. Consequently, they assert their pride in who they are and demand the right to be accepted, transforming their troubled identities into a source of both political and personal strength.

An overwhelming and persistent fear of being arrested, detained and deported makes them feel hopeless and depressed, especially since they are haunted by the prospect of not only losing friends but also parents and siblings. An undocumented status precludes important rites of passage, such as obtaining a driver's license, a bank account, medical insurance, getting an after-school job, financial aid for college or travelling outside of the U.S., and thus exacerbates their position in the school-based peer group. In the long run, lacking a Social Security number or any other credentials, they have little choice but to enter the informal, low-wage labor market, so illegality becomes a binding constraint that informs all spheres of their lives and affects their future. They are cautious in public and attentive to anything that might reveal the truth about their predicament, as any subversion to authority might end with their deportation. They have little which could be perceived as public life and no hope for civic integration, as their undocumented condition supersedes their reality. The political branding of undocumented students as "illegal" creates a stigma around their entire beings, taking away control and a sense of agency.

All three novels proliferate an image of the first-generation immigrant children as devoted to their studies, highly ambitious and academically gifted, in spite of their low socioeconomic status. In fact, a university-bound valedictorian is one of the most common characters in narratives about undocumented youth, the other being a criminal. Jasmine's characterization reinforces the universal Asian-American academic success myth: "You're so perfect, Jasmine. You do everything right. You were junior class president. Cheer captain. Honor Roll. Volunteering" (Cruz 13). The educational stereotype is extended to MT, a Latina, who declares: "I can pass most tests without a lot of effort. I sit in class when it's taught and then I just kind of know it for the test. I read fast" (Andreu 21). These stereotypes repeat a biased and limited perspective of inherited advantages in cognitive abilities that does not reflect the group's heterogeneity and results in its homogenous perception that overlooks social and economic variation. Moreover, promoting an image of undocumented youth as high achievers obscures the challenges that those less capable face. In cases of failure, such students put the blame on themselves, not the system, which adds to the stress and stigma of being undocumented.

On a different note, all novels present academic success stories which are authored by female protagonists. Their accomplishments battle gender stereotypes that position male students as more capable than female, and portray girls from immigrant background as smart, capable, and diligent, even if the achievements they enjoy at school are not always mirrored later in life. Academic success is presented as an empowering element and an important drive for the protagonists, a positive lens they can define themselves through. A sense of educational achievement becomes 
a source of power they can draw from when other aspects of life fail. However, it is also an enormous emotional burden on young people - a constant pressure to succeed and the realization that their whole lives depend on it. And not only theirs, as they carry the responsibility for their families: "With this opportunity, I'll be able to take care of my parents someday. I'll be able to give them the lives they wanted to give me" (Cruz 39). For adolescent immigrants, gaining an education, especially being the first one in the family to graduate from high school, is one of the available and plausible avenues for social ascent and a prerequisite to independence, while forging a new cultural identity. The level of education achieved is a significant barrier to socio-economic advancement, with the sense of self-esteem being an important predictor of achievement. The possibility to continue their education will boost opportunity and help strengthen their financial situations over the long term, and that is why it is so hard for them to resign from it due to their illegal status.

In the pursuit of education, the protagonists are strongly assisted by their parents: MT's mother takes a janitor's job at the Catholic School to pay the tuition, and for Jasmine's parents: "school is all they care about [...] It's always, how did you do on your test, did you get an A, did you get all your work done?" (Cruz 32). As the narratives show, immigration brings about shifts of power in economic and social capital, as well as in relations within families, in both expected and unexpected ways: "This country makes kids snotty and disrespectful" (Andreu 78), complains MT's father. While providing the children with more opportunities and broadening their horizons, the experience of immigration is accompanied by a widening of the generation gap and may result in intergenerational cultural dissonance: "If I do go to college, my life will become even more different from hers. If I don't go, I know I'll never live up to her dreams for me" (Cruz 116), deliberates Jasmine. The narratives favor access to public education ${ }^{3}$ but present a broader perspective which reveals the competing motives that underscore the process of education for immigrant children. During adolescence, young people tend to attach more importance to their peers than family, with parents often becoming a target of subversion. However, for undocumented protagonists this scenario is disrupted because as much as they want to rebel against the parents' authority, they still have to rely on their protection and support regarding their legal status. The parental bonds might weaken as they mature and become more self-conscious and autonomous beings, although their legal insecurity limits their independence throughout the process.

In fact, school is the only official establishment where the stigma of the protagonists' undocumented status can be assuaged: "while most undocumented parents continuously fear US authorities, their children start their lives in relatively safe educational institutions" (Eisema, Fiorito, and Montero-Sieburth 25). Undocumented kids are entitled to K-12 education just like any other citizen or legal resident, which means free or reduced-price meals, special education services, and school-sponsored events and activities. As school authorities are not obliged to report them to the U.S. Immigration and Custom Enforcement (ICE) agents, undocumented students can enjoy their high school in a protected environment. The

Plyer v. Doe (457 U.S. 202 (1982) The U.S. Supreme Court issued a decision that undocumented immigrant children have the right to public education from kindergarten to $12^{\text {th }}$ grade. 
school is also identified as the only venue where native-born, privileged Americans and undocumented immigrants can meet. Even though the protagonists experience no racial or ethnic discrimination and are accepted members of their peer groups, they are well aware of how different their lives are due to their undocumented status: "smoking pot was a privilege afforded to American teenagers and not us undocumented kids. If Evan got caught getting high, he could go to juvie. If I got caught, I'd have a criminal record that could be grounds for deportation" (Andreu 192), explains MT. Jasmine is also alert about her vulnerable status: "I can't afford to mess up like other kids. I'm an immigrant in this country" (Cruz 22). With this realization, they have to mediate among the peer group pressure, the desire to be accepted, and the fact of being undocumented, all amid the general confusion and stress of adolescence.

All three girls see America as their home, and the idea of returning to the native country they barely know is frightening: "This is home," (Andreu 33), asserts MT. Jasmine also cannot imagine leaving the U.S.: "There's no way I can go back to live in the Philippines. I can barely speak Tagalog. My life is here. In America" (Cruz 41). We can observe a perceptive gap between their identification as Americans and their citizenship status. All three protagonists represent hybrid identities, which means they embrace elements of both American and home culture. Their characterization mirrors a sociological concept of selective acculturation, defined by Portes and Rumbaut as being when children acculturate to American ways without abandoning their parents' language and key elements of their culture (267). The parents' criticism towards American ways - "They put their old people in old age homes to die alone. All they care about is money. We're not like them" (Andreu 192) - promotes partial acculturation of their children over complete. Not wanting to see their kids fully and unconditionally assimilated, parents instill in them respect and love for their native cultures: "one of my parents' biggest fears after we immigrated to America was that we would abandon the most significant qualities of Iranian culture: our morals, our loyalty to and love for our family, our hospitality, and the lifelong desire to be kind and polite to others" (Saedi 53), admits Sara, adding that "[s] he feels ethnic pride when Iran wins with the US" (Saedi 101). Selective acculturation is thus shown not only as possible but also encouraged, as young protagonists do not want to be raised ignorant of their heritage. This is why they reject complete assimilation in favor of a hybrid ethnic identity, which is created in response to conditions in America. Forging a culturally "white" identity while maintaining a distinctive ethnicity not only locates them in an in-between space, but also points to their awareness of white privilege. From another perspective, their acculturation is another factor which complicates their status. Since the protagonists were raised primarily in the US, they situate themselves between the common image of immigrants seen as outsiders ignorant of American culture and customs, and the native born members of the society. Due to their acculturation, 1.5 generation immigrant children elude identification with a stereotype of undocumented immigrants as not speaking English, ignorant, and prone to criminal behavior. Location in-between alien and familiar, legal and illegal obfuscates their position, subverting "judgments about immigrants which are rooted in black-andwhite arguments about 'law and order' and the United States' sovereign right to set immigration limits" (Torre, and Germano 464). Cultural proximity to U.S. citizens 
obscures classification of undocumented youth and demonstrates complexity in pronouncing someone as (un)documented, regardless of the person's actual status.

From the standpoint of undocumented immigrants, the narratives offer criticism of American immigrant policy, exposing a society that is deeply divided along class and color lines. The dynamics of power are illustrated by acts of discrimination, both systemic and individual: "They want us to work in their businesses, but they don't want to let us stay here legally, get licenses, have normal lives?" (Andreu 33). An initial sacrifice upon immigration is a decline in social position, as foreign certificates are rarely observed in the U.S.: "My mom graduated top of her class in the Philippines, but in America she cleans up vomit in a hospital" (Cruz 17). Jasmine compares daily immigrant struggles to a game of cat and mouse: "a life of working under the table, for less than minimum wage, with no way to report workplace abuses and transgressions," asking rhetorically: "What happens when they get sick? What happens if they're hurt?" (Cruz 237). Discrimination on a personal level manifests itself in the form of disrespect and ignorance from the natives: "But who are you? You are nothing! You can't do anything in this country. You hate Argentina so much, but Argentina is your only chance, because in this country you're dirt, you're nothing! Serving these losers who think they're better than you" (Andreu 35), exclaims MT's father, who once dreamed of being an architect, and who is now "thirty-nine, and he is still a waiter" (Andreu 30). Jasmine observes American society as class-ridden: "There are the Carries and Royces of the world, high up in their gated mansions and their fancy schools, and then there's me and my family, who are just struggling to keep our footing" (Cruz 100). Even if the U.S. is presented as a multicultural society, in which different ethnic groups live side by side, they still know little about one another. This observation is especially fitting for relationships between whites and people of color, which are tainted with a hint of racial discrimination after the tragedy of 9/11: "there was more tolerance in American society - "[t]he Muslims I knew didn't have to be afraid to be seen in public wearing the hijab the way they are today" (Saedi 84). Discrimination against immigrants, or nativism, is often intertwined with racism, and Sara wonders "if [her] race automatically put[s her] at a disadvantage" (Saedi 39). Walter J. Nicholls supports the critical depiction of the U.S. immigrant policy presented in the novels, pointing out that "[r]epressive measures ran up against liberal legal norms, economic needs of employers, the resource constraints of law enforcement agencies, and humanitarian and moral concerns of the public" (22).

The official government policy that disapproves of illegal immigration is expressed by a civics teacher: "Well, they don't want to learn the language, for one," she says. "And they just don't have the work ethic. Just waiting for a handout. Our system today is overloaded and we can't keep taking all these people who are sneaking across the border like thieves in the night. If they could just do it like our grandparents did..." (Cruz 73), referring to immigration to the U.S. at the turn of the 20th century. Similarly negative sentiments are expressed by Jasmine's American-born friend, Carrie, who asserts: "Personally, I think that whole argument about immigrants being productive members of American society is pretty weak," adding: "Anyone who entered the United States without proper documentation is technically a criminal. They aren't law-abiding people. Obviously." (Cruz 78-9). Nativeborn Americans' resentment towards undocumented immigrants is abetted by their 
acceptance of stereotypes regarding undocumented Latinos and Muslims who are prone to extremism: "illegal aliens are as good as criminals, and deserve punishment rather than mercy" (Cruz 31). Such portrayals are broadcast by official media through images of "Latino field workers and housekeepers" in "high-risk rural areas where drugs and undocumented aliens are routinely smuggled" (Cruz 64), or "the long beard and turban - 'imam' accessories that men now associate with stereotypes like terrorism" (Saedi 13). The angry rhetoric, which mirrors the current antiimmigrant propaganda, provides a fitting context for the fictional representations, with whom the readers can easily identify. This juxtaposition softens the arguments and helps to subvert the official stance. Castro-Salazar and Bagley signal the importance of such representation to those excluded from the mainstream: "Counterhistory, an alternative understanding of the official version of history, is necessary for the construction of a more democratic society" (30).

As characterized by Maia Pank Mertz and David K. England in "The Legitimacy of American Adolescent Fiction" modern adolescent literature should be "hopeful" (119-23). Hence, there is a happy ending for all three protagonists, as they are allowed to stay in the U.S. The Secret Side of Empty ends on the announcement of the President's executive decision on Dreamers, young people who were brought to the U.S. as kids. The narrator explains: "this is not amnesty, this is not immunity. This is not a path to citizenship. It's not a permanent fix. This is a temporary stopgap measure that lets us focus our resources wisely while giving a degree of relief and hope to talented, driven, patriotic young people" (Andreu 195). Even though it gives only a temporary protection, MT is happy as "[t]his means college and a work permit" (Andreu 196). Cruz's novel also ends on an optimistic note, with the threat of deportation averted when Congressman Blakely pulls some strings of his own. The final episode brings the familiar Thanksgiving-like scene - a feast, at which an immigrant Filipino family bonds effortlessly with Congressman Blakely's family: "Mom is teaching Mrs. Blakely how to stuff and roll lumpia" (Cruz 313). An overall mood of ethnic tolerance, acceptance, and happiness permeates the scene. Saedi's memoir ends happily as well, with the protagonist finally obtaining her citizenship, after living for twenty-four years in the U.S. Getting a mock divorce, allowing themselves to be treated with disdain by agents, spending money on lawyers, and seeking help of the extended family finally proved worthwhile, as they can continue with their American lives.

Even though all three novels carry a positive message for undocumented immigrants, each of them highlights a different aspect of their lives. Family, which is an important part of an immigrant life, may exert a positive or negative influence. Andreu shows the destructive impact of the experience of immigration on the family, whose members cannot cope with its negative effects, such as poverty and loss of power and dignity. MT finds little support in her parents, whose frustration and anger at their predicament finds no constructive vent. Jasmine and Sara, on the contrary, fully rely on the financial and emotional support of their parents and siblings, which alleviates their anxiety and allows them to better cope with daily struggles. The unrelenting strength of family ties is depicted as the true source of power, which helps the two families combat the hardships of life. Thus, the efficacy of family support is argued as a protective factor in the process of assimilation and acculturation of the adolescent protagonists. 
The legal/illegal binary, which informs my essay, affects the immigrant's reflection of herself and the surrounding world, resulting in family fragmentation (Cruz's story) or personal trauma (Andreu's and Saedi's stories). Insecurity about the future breeds anxiety about the protagonist's identity. Lacking the security of their native countries, and with no protection in the host one, the protagonists feel uprooted and lost, having to fend for themselves: "I may look like I belong in the Philippines, but they'll know I'm a fraud too. I can't even speak Tagalog or Ilocano. Neither country will want me" (Cruz 228), admits Jasmine, referring to the realization of loss, which is an inherent part of the experience of immigration. "I'm constantly balancing my American-ness with my Iranian-ness. I'm the combination of two worlds and cultures" (Saedi 182), adds Sara. Straddled between the two cultures, MT explains: "I will always be a stranger everywhere. With my parents, I am too American. With Americans, I am a spectator with my nose pressed against their windowpanes, watching their weird rituals and rites of passage, never quite understanding them completely" (Andreu 59). The protagonists, who represent culturally diverse adolescents, must handle various influences, deriving from the realm of family and society. In the process, they try to negotiate, reconcile and make sense of both worlds, while forming their own sense of selfhood. However, illegality obscures the promise of America, so the American identity that the novel imagines for and makes available to the undocumented immigrant becomes illusory.

Both Andreu's and Cruz's fictional narratives advance an image of tolerant and helpful white, rich, native-born Americans, who generously devote their time and resources to helping poor and mostly ignorant immigrants. American-born school friends and their parents show no prejudice, but compassion and concern for the protagonists. Their help is the prerequisite for success that promotes the image of mainstream society as progressive and open-minded. Both MT and Jasmine engage in romantic relationships with all-American boys, who are understanding and supportive. The romantic plots and friendships allow the protagonists to develop, which in Beyond Ethnicity Werner Sollors calls "the construction of new forms of symbolic kinship," (7) social ties that allow them entrance and inclusion into mainstream society. Crossing ethnic and class divisions, these consensual relations certify that immigrant protagonists are ready to be accepted as Americans and undermine their undocumented status. If in the eyes of "real Americans" they are seen as equal, why should not they be by law? By way of contrast, Saedi's memoir depicts the legal struggles of her family, which are abetted only by expensive and sometimes dishonest immigration lawyers. There are no prominent benefactors or advisers, who would be willing to pull some strings for them. In the legal battle, the immigrant family is left to their own devices.

All three texts are devoid of experiments in narrative techniques, favoring realism as the medium of literary communication. Thus, they clearly represent the factual elements of the story so that the choice of style does not make the plot confusing. Code switching, which signals the protagonists' native languages, such as Filipino lumpia and pancit (Cruz 151), Spanish abuela (Andreu 32) and Farsi Baba (Saedi 9), helps to establish the realistic nature of foreign-born characters. Non-English words delineate the domestic sphere, referring to the members of the family or home foods. The tone is predominantly matter-of-fact, with a dose of satirical humor, which assuages the gravity of the subject matter. Salas claims that "[a]dolescents should not 
only see themselves honestly represented in texts but should also be able to learn about their peers through realistic portrayals" (12). Realism is informative to the readers, as it deals with problems and solutions applicable to real life and culture. The novels offer accurate representations of how the experience of illegality impacts the emotional and mental development of the characters and reflections on their lives, even if its portrayal is largely sanitized. The power of personal experience, especially of those marginalized by the mainstream society, becomes the source of authorization, adding to its relevance for the readers. The significance of individual experience also determines what is important and representative, giving prominence to the socio-political reality of the stories. Similarly, the potential of storytelling as a means of self-actualization, to borrow Maslow's term, testifies to its viability in the context of political engagement. All three narratives are employed to comment on the politics of immigration in the U.S., and by doing so help to activate the readers' social and political awareness, such as for example instigated by the DREAM Act in 2001. Kurzman supports the view, claiming that social movements are an especially interesting site of meaning-making because they are actively and continually producing culture, knowledge and strategies that challenge particular powerful, interrelated and often taken-for-granted institutions, ideas and ideologies (5-7).

Apart from the fictional narrative, all the authors include additional information on the topic of illegal aliens. Paratext, to use Genettes' term (Paratexts: Thresholds of Interpretation), influences the way the readers interpret the main narrative. Both Mary E. Andreu and Melissa de la Cruz include Author's Notes, in which they refer directly to their readers, recalling their own experiences of being undocumented immigrants, and their arduous journeys to become U.S. citizens. Such authorial information gives a sense of authenticity and credibility to the fictional narratives that appear more believable to the readers. Andreu highlights important issues raised in her novel, such as domestic violence and suicide, encouraging her readers to seek help when in need. In the section entitled Resources, she provides web addresses and a phone number of a suicide crisis hotline. At the beginning of each chapter Cruz offers inspirational quotes by politicians (George Washington, Barack Obama), sportsmen (Zinedine Zidane, Lolo Jones), writers (Chuck Palahniuk, Paulo Coelho), fashion designers (Coco Chanel), lawyers (Clarence Darrow), producers (Shonda Rhimes), artists (Frida Kahlo), activists (Malala Yousafzai), and the British royal family (Princess Diana). These words from well-known and popular figures hold more gravitas because of the public positions held by those people. At the end, Cruz also includes a number of questions for discussion, which refer to the problems raised in her novel, such as immigration, assimilation, racial prejudice, and identity.

Contrary to Andreu's and Cruz's fictional narratives, the Introduction to Saedi's text orients its reading and interpretation as a fictional memoir. It informs about the origin of the text, which is the moment she learns that her family is in the U.S. illegally, and explains the title. Saedi's fictional memoir at times looks like a manual for undocumented immigrants, in which the protagonist's story is a pretext to exemplify and explain various routes to citizenship. In the section entitled Your undocumented immigrant refresher course! (186-89S), the author includes much practical information about the legal process. The narrator addresses the readers directly, which creates a sense of immediacy and intimacy. The pronoun "you" engages the narrator and the reader in a form of a private conversation. The employment of the second person 
narrative voice allows the emergence of a textual figure with which the readers are encouraged to identify, either as "it is me" or as "it could be me." It also allows one to render the essential information devoid of formal pretentiousness, making it more accessible. Likewise, the inclusion of passages from the author's personal journals functions as a provider of testimony to the narrative. A large dose of humor makes Saedi's story more lighthearted, and it does not carry the burden of loss and disappointment, as the other two texts do. While Cruz's and Andreu's novels offer limited insight into the lives in their native countries, Saedi's narrative starts with a crash course on Iranian history. In an epilogue, the narrator imagines what her life would be like if she had stayed in Iran. Throughout the whole memoir, the author asserts that ethnic pride and American patriotism are not opposing concepts, nor do public manifestations of ethnic heritage undermine her loyalty to the adopted home.

In line with the mainstream expectations, all three undocumented protagonists are shown not as law-breaking criminals but as potential citizens. Cast as "deserving immigrants," they help to soften anti-immigrant sentiments in the U.S. They represent the concept of "good immigrants" who should be worthy of U.S. citizenship, promoting desirable features such as hard work, frugality, compliance, and respect towards the local culture and law. Through their actions and conduct, they express eagerness to contribute to and be productive members of the community. This positive image of undocumented immigrants counters the official derogative rhetoric, such as that promoted by President Donald Trump at his rallies and speeches: he sees them as "invaders", "animals", and "bad people" who "infest" the country (Salas 11). On the other hand, the overtly positive and sanitized characterization of undocumented youth reduces the immigrant body to that part which is welcomed and endorsed by the official immigrant discourse, disregarding those who are just as fallible as any other human. Julio Salgado, an undocumented activist, questions such expectations, asserting his lack of interest in being anyone's model citizen-awaitingpermission in an unjust system: "Not everybody is a perfect immigrant ... this idea that we're trying to show how good we are and how we constantly have to ask for forgiveness, I'm tired of that. I'm not going to be on my knees and ask for forgiveness, because nobody's perfect" (Lewthwaite 452).

The authors imagine the immigrant experience from the perspective of undocumented immigrants, whose voices, up until recently, have largely been absent (or perhaps more accurately, disregarded and unheard) in the public cultural and political discourse on immigration. Despite their legal erasure, fictional representations make undocumented immigrants more visible and therefore, in a way, protected, while regaining their own voices makes them subjects, not objects, of official history. Even though the novels discussed refer only to three ethnic immigrant groups: Argentinian, Filipino, and Iranian, and overlook the biggest one -Hispanics - they echo the stories of other involuntary immigrants who came to the U.S. as minors. What they all share are the stories of personal fear, humiliation, and hope. On a broader scale, their voices interact with and against labels such as "illegal alien" and "undocumented," in the process changing what they mean. All three fictional accounts are political and deeply embedded in the relations of power, as narrated by the victims of unjust structures, and encourage critique of the system. In other words, "[t]heir counter-narratives, counter-majoritarian stories situated in a counter-historical dimension, contest the colonizers' constructed histories and oppose the exclusionary 
notion of who 'belongs' in the United States" (Castro-Salazar, and Bagley 7). By inviting multiple perspectives, they present a different version of life in the U.S. and inspire a critical approach towards the issue of immigration. Finally, the narratives which feature undocumented protagonists assist mainstream society in becoming more culturally sensitive to the needs and experiences of newcomers, and promote every immigrant's right to exist and pursue their own dreams of belonging.

\section{References}

Andreu, Maria E. Secret Side of Empty. Running Press, 2014.

Castro-Salazar, Ricardo, and Carl Bagley. "Navigating Borders: Critical Race Theory Research and Counter History of Undocumented Americans." Counterpoints 415 (2012): 3-36.

Cruz, Melissa de la. Something in Between. Harper Collins, 2016.

Eisema, Dirk, Tara Fiorito, and Martha Montero-Sieburth. "Beating the Odds: The Undocumented Youth Movement of Latinos as a Vehicle for Upward SocialMobility." New Diversities 16.1 (2014): 23-39.

Genette, Gerard. Paratexts: Thresholds of Interpretation. Trans. Jane E. Lewin. Cambridge: Cambridge University Press, 1997.

Kurzman, Charles. "Meaning-making in Social Movements." Anthropological Quarterly 81.1 (2008): 5-15, https:/ / doi.org/10.1353/anq.2008.0003.

Lewthwaite, Stephanie. "Immigration Forum Comment: Cultural Responses to Immigration. Journal of American Studies 50.2 (2016): 449-58, https://doi.org/10.1017/S002187 5816000505 .

Maslow, Abraham. “A Theory of Human Motivation.” Psychological Review 50 (1943): 370-96, https://doi.org/10.1037/h0054346.

Mertz Pank, Maia, and David K. England. "The Legitimacy of American Adolescent Fiction." School Library Journal 30. 2 (1983): 119-23.

Nicholls. Walter J. The Dreamers: How the Undocumented Youth Movement Transformed the Immigrant Rights Debate. Stanford, CA: Stanford University Press, 2013.

Plyer v. Doe (457 U.S. 202 (1982) <https:/ / www.loc.gov/item/usrep457202/>. Accessed Jan. 22, 2019.

Portes, Alejandro, and Rubén G. Rumbaut. Immigrant America: A portrait (3rd edition). Berkeley: University of California Press, 2006.

Rumbaut, Rubén G. "Generation 1.5, Educational Experiences Of." Encyclopedia of Diversity in Education, edited by James A. Banks, Sage Publications, 2012. Available at <https://ssrn. com/abstract $=2182167>$.

Saedi, Sara. Americanized: Rebel without a Green Card. New York: Random House, 2018.

Salas, Rachel G. "Under the Shadow of Trump: Portrayals of Undocumented Youth in Young Adult fiction from 2016-2017." Forum on Public Policy 2018.1. < http://forumonpublic policy.com/journals-2/online-journals/volume-2018-no-2/>. Accessed online December 5, 2019.

Torre III, Pedro de la, and Roy Germano. "Out of the Shadows: DREAMer Identity in the Immigrant Youth Movement." Latino Studies 12 (2014): 449-67, https:/ / doi.org/10.1057/ lst.2014.45. Accessed online December 5, 2019.

Sollors, Werner. Beyond Ethnicity: Consent and Descent in American Culture. New York: Oxford University Press, 1986. 